\title{
Konsep diri dan motivasi melanjutkan pendidikan ke perguruan tinggi pada remaja panti asuhan " $x$ "
}

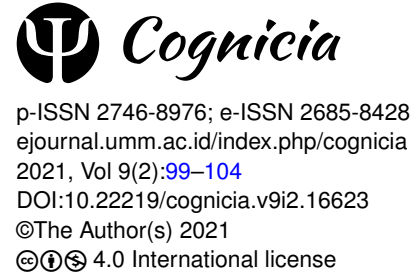

Tanri Fatma Utami ${ }^{1}$ dan Rahmah Saniatuzzulfa ${ }^{2}$

\begin{abstract}
The low number of high school graduates in Purworejo who continue their education to college is caused by the students' concerns about the high cost of education and lack of student confidence in their abilities. One of those who experienced this was an orphanage teenager. Teenagers in orphanages are teenagers who are deliberately entrusted by their parents to get a decent life and education. This study aims to determine the relationship between self-concept and motivation to continue education to college. The sample recruitment was determined using cluster random sampling method and found 81 teenage orphanages as participants. The instruments used are the Motivation Scale Continuing Education to Higher Education with $43(a=0.930)$ and the Self Concept Scale with $25(a$ $=0.870)$. The results of a simple regression analysis showed that there is a significant positive relationship between self-concept and motivation to continue education to college ( $\mathrm{F}=105.700 ; p<0.05 ; \mathrm{r}=0.756)$. SE contributed $57,632 \%$ of the motivation to continue their education to college.
\end{abstract}

\section{Keywords}

Motivation to continue study to the college, orphanage teenager, self-concept

\section{Pendahuluan}

Pendidikan merupakan suatu upaya pembangunan yang dilakukan oleh beberapa kalangan seperti keluarga, pemerintah, maupun masyarakat yang dilaksanakan melalui aktivitas pengajaran, bimbingan, serta latihan secara formal maupun non-formal, yang berlangsung di lingkungan sekolah, atau luar sekolah sepanjang masa yang bertujuan mempersiapkan individu untuk dapat memainkan peranan di lingkungan sosial (Lestari, 2016). Selain pendidikan wajib dua belas tahun, di Indonesia juga terdapat perguruan tinggi. Meskipun perguruan tinggi bukan merupakan pendidikan yang wajib ditempuh, akan tetapi perguruan tinggi memiliki manfaat yang tak kalah penting bagi kehidupan individu diantaranya memberikan perubahan taraf hidup yang baik dan berkualitas seperti pekerjaan dan penghasilan yang lebih layak, memiliki tingkat pergaulan yang lebih luas dan bermanfaat bagi masa depan, memiliki pengetahuan dan daya kreativitas tinggi yang digunakan untuk kehidupan sehari-hari serta bersaing dalam dunia kerja, juga lebih dihargai dalam menjalani gaya hidup (Biantara, 2016)

Ali (2017), menguraikan bahwa banyak alumni SMA/SMK di Kabupaten Purworejo tidak meneruskan pendidikannya ke perguruan tinggi dengan berbagai alasan, di antaranya ketakutan orang tua akan biaya pendidikan yang tinggi, minimnya wawasan atau informasi tentang perguruan tinggi di Purworejo, dan kondisi ini diperparah dengan keraguan siswa terhadap potensi yang dimilikinya sehingga khawatir tidak mampu masuk kuliah karena sulitnya seleksi pada pendaftaran awal. Berdasarkan hasil wawancara yang peneliti lakukan terhadap 15 anak asuh pada Hari Senin, 30 April 2018 di Panti Asuhan "X", menyatakan bahwa sebagian besar anak asuh yang sudah atau akan lulus sekolah mengalami ketakutan-ketakutan tersebut.

Lembaga masyarakat yang berfungsi menampung anakanak terlantar dan kurang mampu dengan tujuan untuk mencukupi segala kebutuhan anak-anak tersebut disebut dengan panti asuhan (Khoirunnisa, et.al, 2015). Seorang anak ditempatkan di panti asuhan oleh keluarganya sebagian besar disebabkan oleh kesulitan ekonomi (Mecadinisa, 2018). Keputusan ini dilakukan untuk memastikan bahwa anak-anak dari keluarga yang mengalami kesulitan ekonomi ini mendapatkan pendidikan secara layak (Ningrum, 2012).

Melanjutkan pendidikan ke perguruan tinggi tentunya membutuhkan motivasi. Motivasi menjadi salah satu faktor dalam menentukan keberhasilan seseorang, antara lain pada bidang studi, pekerjaan, dan lain sebagainya. Hal ini dikarenakan dengan motivasi akan mampu mengarahkan

\footnotetext{
${ }^{1,2}$ Universitas Sebelas Maret, Indonesia

Korespondensi:

Rahmah Saniatuzzulfa, Program Studi Psikologi Fakultas Kedokteran Universitas Sebelas Maret

Email: rahmahsaniatuzzulfa@staff.uns.ac.id
} 
seseorang untuk berbuat dan menyeleksi perbuatan yang baik atau yang tidak baik (Sardiman, 2014). Motivasi dalam diri seseorang berbentuk suatu proses diinisiasikannya dan dipertahankannya suatu aktivitas yang mengarah pada pencapaian tujuan (Schunk, et.al2012). Motivasi memberikan dorongan dalam diri untuk meningkatkan kemampuannya dalam keinginan atau cita-cita yang ingin dicapai yang memberikan penghargaan financial. Hal ini sejalan dengan pernyataan Hamalik (1992) yang menyatakan bahwa motivasi adalah perubahan energi atau tenaga dalam diri pribadi seseorang yang ditandai dengan timbulnya perasaan yang mengarah ke tingkah laku seseorang untuk mencapai tujuan tertentu.

Timbulnya motivasi pada diri seseorang dipengaruhi oleh faktor eksternal maupun faktor internal, salah satunya adalah konsep diri (Khan \& Alam, 2015). Franken (Huitt, 2009) menyatakan bahwa konsep diri dapat dikatakan sebagai landasan perilaku. Konsep diri yang positif membuat diri meningkat menuju pada diri ideal, dan diri ideal menimbulkan motivasi pada perilaku. Konsep diri yang positif akan mempengaruhi munculnya keinginan dalam diri individu untuk berhasil dalam segala hal (Calhoun \& Acocella, 1990).

Calhoun \& Acocella (1990) mengatakan individu yang memiliki konsep diri positif akan mengenal, menerima dirinya dengan baik, mampu merencanakan tujuan yang berpeluang besar untuk dicapai, serta menganggap bahwa kehidupan merupakan suatu proses penemuan. Hal ini disebabkan individu tersebut mampu memahami dan menerima sejumlah fakta mengenai dirinya secara positif. Sebaliknya, apabila konsep diri negatif, maka berpengaruh pada perilaku-perilaku destruktif dan pada akhirnya akan menghambat pencapaian cita-citanya. Pada remaja panti asuhan memiliki berbagai macam latar belakang yang dapat mempengaruhi konsep dirinya (Merina, 2014). Anak asuh seringkali dianggap memiliki status sosial yang rendah di masyarakat luas, karena panti asuhan dianggap sebagai tempat meminta belas kasihan orang (Mazaya \& Supradewi, 2021). Menurut penelitian yang dilakukan oleh Sahuleka (2003) panti asuhan memberikan dampak positif dan dampak negatif bagi idividu yang tergabung di dalamnya. Positifnya, panti asuhan dapat menjadi tempat bernaung bagi anak-anak kurang mampu maupun remaja yang terlantar dimana mereka mendapatkan bimbingan dalam bidang pendidikan dan pekerjaan maupun dalam pembentukan karakter dan penyesuaian diri di masyarakat, dan merupakan suatu lingkungan theurapeutic bagi anak-anak serta remaja yang membutuhkan. Sedangkan dampak negatifnya, kehidupan remaja panti asuhan memungkinkan remaja mengalami penurunan emosi yang mengakibatkan kecenderungan gangguan kepribadian seperti sikap menarik diri, tidak mampu membentuk hubungan yang hangat dan dekat dengan orang lain, kurang dapat menyesuaikan diri, sehingga hubungan mereka bersifat dangkal dan tanpa perasaan.
Berdasarkan uraian di atas, peneliti ingin mengetahui lebih lanjut mengenai motivasi melanjutkan pendidikan ke perguruan tinggi, khususnya yang berkaitan dengan konsep diri dengan melakukan penelitian yang berjudul hubungan antara konsep diri dengan motivasi melanjutkan pendidikan ke pergurun tinggi pada remaja Panti Asuhan "X".

\section{Metode}

Teknik cluster random sampling dipilih sebagai cara pengambilan sampel, yakni melalui cara mengundi lembaga panti asuhan "X". Cara undian dilakukan dengan membuat gulungan kertas yang berisi nama-nama panti asuhan, kemudian diundi untuk dijadikan sampel penelitian dan terpilihlah panti asuhan "X". Pada panti asuhan "X" didapatkan jumlah sampel sebanyak 81 orang.

Penelitian ini menggunakan pendekatan analisis kuantitatif. Pendekatan kuantitatif menurut Azwar (2011) fokus analisisnya adalah pada data-data numerikal yang dibuat dengan metode statistika. Peneliti menggunakan desain penelitian korelasional untuk mengetahui hubungan konsep diri dan motivasi melanjutkan pendidikan ke perguruan tinggi pada remaja panti asuhan " $\mathrm{X}$ "

Alat ukur yang digunakan dalam penelitian ini yang pertama adalah Skala Motivasi Melanjutkan Pendidikan ke Perguruan Tinggi. Pengukuran motivasi melanjutkan pendidikan ke perguruan tinggi ini dibuat oleh peneliti berdasarkan pada aspek-aspek motivasi melanjutkan pendidikan ke perguruan tinggi yang dikemukakan oleh Cherniss \& Goleman (2001), yaitu dorongan untuk mencapai sesuatu (achievement drive), komitmen (commitment), inisiatif (initiative), dan optimis (optimism). Skala Motivasi Melanjutkan Pendidikan ke Perguruan Tinggi yang digunakan dalam penelitian ini berjumlah 43 item dengan nilai reliabilitas $a=0.930$.

Alat ukur kedua yang digunakan dalam penelitian ini adalah Skala Konsep Diri. Pengukuran konsep diri ini dimodifikasi dari skala konsep diri milik Hartiyani (2011) yang terdiri atas 28 aitem $(a=0.824)$ dan memiliki daya diskriminasi aitem berkisar antara $0.272-$ 0.784 berdasarkan pada aspek-aspek konsep diri yang dikemukakan oleh Berzonsky (1981), yaitu aspek fisik, aspek sosial, aspek moral dan aspek psikis. Skala Konsep Diri yang digunakan dalam penelitian ini berjumlah 25 aitem dengan nilai reliabilitas $a=0.870$.

Sistem penilaian (scoring) dalam Skala Motivasi Melanjutkan Pendidikan ke Perguruan Tinggi dan Skala Konsep Diri menggunakan skala likert yang dimodifikasi menjadi empat pilihan jawaban yang dibagi menjadi pernyataan favorable dan pernyataan unfavorable yang menggunakan empat tipe pilihan, yaitu sangat sesuai (SS), sesuai (S), tidak sesuai (TS), dan sangat tidak sesuai (STS) dengan menghilangkan pilihan ragu-ragu sehingga subjek akan memilih ke arah yang sesuai dan tidak sesuai dengan diri subjek. Skala dengan empat alternatif jawaban lebih disarankan karena apabila ada lima alternatif jawaban, 
subjek cenderung memilih alternatif jawaban yang ada di tengah, yang dirasa aman dan hampir tidak berpikir (Arikunto, 2006).

Metode analisis data yang digunakan pada penelitian ini adalah Analisis Regresi Linier Sederhana. Analisis ini digunakan untuk mengetahui arah hubungan antara variabel prediktor (Konsep Diri) dengan variabel kriterium (Motivasi Melanjutkan Pendidikan ke Perguruan Tinggi) apakah variabel prediktor berhubungan positif atau negatif dan untuk memprediksi nilai dari variabel kriterium apabila variabel prediktor mengalami kenaikan maupun penurunan. Pengolahan data dibantu dengan program SPSS versi 23.0.

\section{Hasil}

\section{Uji Asumsi Dasar dan Klasik}

Berdasarkan hasil uji normalitas dan liniearitas, dapat disimpulkan bahwa persebaran data bersifat normal dan liniear. Begitu pula dengan hasil uji asumsi klasik, tidak terdapat heteroskedastisitas dan autokorelasi.

\section{Uji Hipotesis}

Berdasarkan hasil yang ditulis dalam Tabel 1 dapat disimpulkan bahwa hipotesis diterima yaitu terdapat hubungan positif antara konsep diri dengan motivasi melanjutkan pendidikan ke perguruan tinggi remaja panti asuhan "X". Berdasarkan hasil tersebut dapat ditarik kesimpulan apabila konsep diri menglami peningkatan maka motivasi melanjutkan pendidikan ke perguruan tinggi akan mengalami peningkatan pula. Hal ini ditunjukkan dengan Fhitung $>$ Ftabel, yakni (105.700 > 3.962), $p=0.0(p<0.05)$.

1. Analisis Deskriptif Hasil kategorisasi setiap variabel ditunjukkan pada Tabel 2.

2. Persamaan Regresi Hasil persamaan regresi ditunjukkan pada Tabel 3. Analisis persamaan regresi menunjukkan $\mathrm{y}=38.798+1.230 x 1$. Artinya, semakin tinggi konsep diri, maka semakin tinggi pula motivasi melanjutkan pendidikan ke perguruan tinggi.

\section{Diskusi}

Berdasarkan hasil uji hipotesis dapat diketahui bahwa terdapat hubungan positif signifikan antara konsep diri dengan motivasi melanjutkan pendidikan ke perguruan tinggi pada remaja panti asuhan "X". Hal ini ditunjukkan dengan nilai signifikansi hasil uji regresi linear sederhana sebesar $0.000(p<0.05)$ dengan Fhitung $>$ Ftabel $(105.700>3.962)$.

Hal ini sejalan dengan penelitian Khan \& Alam (2015); Lawrence \& Vimala (2013) bahwa salah satu faktor yang mempengaruhi motivasi adalah konsep diri. Konsep diri mempengaruhi cara padang seseorang pada suatu hal yang akan membentuk perilakunya untuk bertindak dalam berbagai situasi. Individu dengan konsep diri positif, maka akan menimbulkan energi yang positif pula yang kemudian memunculkan motivasi. Individu yang dalam dirinya terdapat konsep diri negatif menurut Calhoun \& Acocella (1990) tidak mengenal dirinya dengan baik karena tidak memahami kelebihan dan kekurangan yang dimilikinya serta memandang dirinya rendah.

Hasil uji hipotesis pada penelitian ini juga menghasilkan nilai $\mathrm{r}=0,756$ yang menunjukkan nilai positif, hal ini berarti konsep diri memberikan kontribusi positif terhadap motivasi melanjutkan pendidikan ke perguruan tinggi. Sumbangan efektif pada variabel konsep diri terhadap motivasi melanjutkan pendidikan ke perguruan tinggi yaitu 57,632\% sehingga dapat dikatakan konsep diri berpengaruh terhadap motivasi melanjutkan pendidikan ke perguruan tinggi pada remaja panti asuhan "X". Berdasarkan hasil tersebut, hipotesis dalam penelitian ini diterima, yaitu terdapat hubungan signifikan dan positif antara konsep diri dengan motivasi melanjutkan pendidikan ke perguruan tinggi pada remaja panti asuhan "X".

Hal ini sesuai dengan penelitian yang dilakukan oleh Septiana (2014) dan Aditi (2021) yang menyatakan bahwa konsep diri mempengaruhi motivasi secara positif, dalam arti semakin baik konsep diri seseorang maka semakin tinggi pula motivasinya. Individu dengan konsep diri positif, memandang dirinya mampu untuk mencapai suatu hal. Pandangan yang baik akan diri sendiri membuat seseorang paham dengan kelebihan dan serta menerima akan kekurangan dirinya.

Apabila dilihat dari aspek-aspek yang ada dalam konsep diri dapat mempengaruhi tingkat motivasi melanjutkan pendidikan ke perguruan tinggi. Aspek sosial, aspek moral dan aspek psikis pada variabel konsep diri dapat mempengaruhi aspek achievement drive pada variabel motivasi melanjutkan pendidikan ke perguruan tinggi. Aspek sosial memengaruhi achievement drive melalui peran sosial yang dijalaninya di lingkungan. Seseorang yang memiliki peranan penting dalam lingkungan serta menilai bahwa performanya pada lingkungan baik, individu tersebut akan terdorong untuk melakukan suatu hal lebih baik lagi. Terlebih apabila seseorang tersebut memiliki tujuan dan standar yang telah ditetapkannya, hasil dari interaksinya dengan orang-orang sekitar akan mempengaruhi munculnya dorongan pada dirinya untuk berbuat sebaik mungkin. Aspek moral mempengaruhi achievement drive melalui prinsip yang memberikan arah bagi kehidupan individu. Apabila seseorang telah memiliki arah hidup, maka tujuan hidupnya pun sudah jelas, akan lebih merasa memiliki kepastian dalam melakukan suatu tindakan sehingga dorongan yang timbul akan lebih kuat. Sedangkan aspek psikis memunculkan achievement drive melaui pikiran dan perasaan individu. Seseorang yang berpikir dan merasa bahwa dirinya mampu dan bisa akan membuat munculnya dorongan untuk mencapai suatu 
Tabel 1. Uji Simulan (F)

\begin{tabular}{lllllll}
\hline ANOVA & & & & & \\
\hline Model & & Sum of Squares & df & Mean Square & F & Sig. \\
\hline \multirow{4}{*}{1} & Regression & 6091.725 & 1 & 6091.725 & 105.700 & $0.00 a$ \\
& Residual & 4552.966 & 79 & 57.632 & & \\
& Total & 10644.691 & 80 & & & \\
\hline
\end{tabular}

${ }^{1}$ ependent Variable: Motivasi; Predictors: (Constant), Konsep

Tabel 2. Kriteria dan Kategorisasi Responden Penelitian

\begin{tabular}{|c|c|c|c|c|}
\hline \multirow{2}{*}{ Variabel } & \multicolumn{2}{|l|}{ Kategorisasi } & \multicolumn{2}{|c|}{ Komposisi } \\
\hline & Kategorisasi & Skor & Jumlah & Persentase \\
\hline \multirow{3}{*}{ Konsep Diri } & Tinggi & $83.75 \leq x$ & 11 & 13.6 \\
\hline & Sedang & $\begin{array}{l}83,75 \\
69.556\end{array} \geq x \geq$ & 55 & 67.9 \\
\hline & Rendah & $X<69.556$ & 15 & 18.5 \\
\hline \multirow{3}{*}{ Motivasi Melanjutkan Pendidikan ke Perguruan Tinggi } & Tinggi & $144.597 \leq X$ & 12 & 14,8 \\
\hline & Sedang & $\begin{array}{l}144.597 \\
121.527\end{array} \geq X$ & 58 & 71.6 \\
\hline & Rendah & $X<121.527$ & 11 & 13.6 \\
\hline
\end{tabular}

Tabel 3. Persamaan Regresi

\begin{tabular}{lllllll}
\hline \multirow{2}{*}{ Model } & & \multicolumn{2}{l}{ Unstandardized Coefficients } & \multicolumn{2}{l}{ Standardized Coefficients } & \multirow{2}{*}{ Sig. } \\
\cline { 3 - 5 } & & $\mathrm{B}$ & \multicolumn{1}{c}{ Std. Error } & Beta & \\
\hline \multirow{2}{*}{1} & (Constant) & 38.798 & 9.207 & & 4.214 & 0.0 \\
& Konsep & 1.230 & 0.120 & 0.756 & 10.281 & 0.0 \\
\hline
\end{tabular}

${ }^{2}$. Dependent Variable: Motivasi

tujuan karena secara langsung diri sendiri sudah merasa siap untuk melakukan sesuatu.

Aspek moral dan psikis juga dapat mempengaruhi commitment pada individu. Nilai dan prinsip pada aspek moral seseorang akan mempengaruhi sifat tanggung jawab pada seseorang terhadap apa yang sudah direncanakan dan akan dituju. Seseoran yang kurang memiliki prinsip dalam hidupnya akan cenderung menganggap enteng rencanarencana yang telah dibuatnya. Selain itu, nilai dan prinsip mampu menyelaraskan kegiatan-kegiatan yang dilakukan agar dapat berjalan dengan seimbang. Aspek psikis pada seseorang akan mengarahkan pikiran, perasaan, dan sikap seseorang untuk focus pada perencanaan yang telah dibuat.

Aspek sosial mempengaruhi initiative seseorang dengan melakukan perbandingan terhadap lingkungan sekitar. Terkadang kebutuhan individu satu dengan individu lain berbeda, akan tetapi seorang individu yang kurang memiliki peranan penting dalam kelompok sosial akan melakukan konformitas pada orang lain yang dianggapnya lebih kredibel padahal tidak semua kebutuhannya sama. Sehingga, agar kebutuhan yang berbeda ini terpenuhi, dibutuhkan inisiatif atau kemampuan melihat peluang bagi individu untuk pemenuhan tujuannya.

Aspek fisik, sosial dan psikis dapat mempengaruhi optimism seseorang. Cara individu memandang kelebihan maupun kelurangan dalam dirinya dapat mempengaruhi kegigihan seseorang dalam menghadapi halangan dan rintangan, serta bangkit dari kegagalan. Lingkungan sekitar yang mendukung segala usaha individu akan membuat individu yakin dan semangat dalam mengejar tujuan yang hendak dicapai. Pikiran, perasaan, dan sikap terhadap diri seseorang jelas mempengaruhi optimism dalam seseorang. Seseorang yang berpikir dan merasa bahwa dirinya bisa akan membuat dirinya menjadi gigih untuk menghadapi segala rintangan dan hambatan serta memberi kekuatan untuk bangkit apabila menghadapi kegagalan.

Hasil kategorisasi data deskriptif motivasi melanjutkan pendidikan ke perguruan tinggi remaja panti asuhan " $X$ " yaitu, subjek dengan tingkat motivasi melanjutkan pendidikan ke perguruan tinggi kategori rendah sebesar $13.6 \%$, kategori sedang sebesar $71.6 \%$, sedangkan untuk tingkat tinggi sebesar $14.8 \%$. Berdasarkan hasil data tersebut dapat ditarik kesimpulan bahwa mayoritas remaja panti asuhan " $\mathrm{X}$ " memiliki tingkat motivasi melanjutkan pendidikan ke perguruan tinggi tergolong sedang. Berdasarkan hasil kategorisasi data deskriptif konsep diri menunjukkan bahwa subjek dengan tingkat rendah sebesar $18.5 \%$, tingkat konsep diri sedang sebesar $67.9 \%$, sedangkan untuk tingkat tinggi sebesar $13.6 \%$. Hasil tersebut menunjukkan bahwa mayoritas remaja panti asuhan "X" memiliki tingkat konsep diri sedang.

Penelitian ini memberikan analisis tambahan pada variabel motivasi melanjutkan pendidikan ke perguruan tinggi yang ditinjau dari jenis kelamin dan usia. 
Berdasarkan data deskriptif pada variabel motivasi melanjutkan pendidikan ke perguruan tinggi ditinjau dari jenis kelamin, mayoritas remaja panti asuhan berada dalam kategori skor sedang dilihat baik itu jenis kelamin lakilaki, maupun jenis kelamin perempuan. Selain itu, hasil skor rerata motivasi melanjutkan pendidikan ke perguruan tinggi pada remaja panti asuhan, menunjukkan paling tinggi berjenis kelamin laki-laki. Dweek dan Nicholls (Wulandari \& Rola, 2004) mengatakan bahwa motivasi berprestasinya wanita cenderung tidak stabil dibandingkan pria. Horner (Wulandari \& Rola, 2004) juga menyatakan bahwa wanita memiliki kekhawatiran akan ditolak oleh masyarakat apabila dirinya memperoleh kesuksesan (fear of success).

Hasil perhitungan menggunakan independent sample $t$ test menunjukkan nilai signifikansi kurang dari 0.05 dalam penelitian ini. Hal ini berarti terdapat perbedaan yang signifikan pada variabel motivasi melanjutkan pendidikan ke perguruan tinggi ditinjau dari jenis kelamin remaja panti asuhan "X". Hasil dalam penelitian ini sejalan dengan penelitian yang dilakukan oleh Wulandari \& Rola (2004), bahwa terdapat perbedaan yang signifikan yang ditinjau dari jenis kelamin.

Berdasarkan data deskriptif pada variabel motivasi melanjutkan pendidikan ke perguruan tinggi ditinjau dari usia, mayoritas remaja panti asuhan berada dalam kategori skor sedang dilihat dari seluruh rentang usia. Selain itu, hasil skor rerata motivasi melanjutkan pendidikan ke perguruan tinggi pada remaja panti asuhan, menunjukkan paling tinggi berada pada rentang usia 19-21 tahun atau berada pada tahap perkembangan remaja akhir. Hasil perhitungan menunjukkan nilai signifikansi lebih dari 0.05 dalam penelitian ini dan nilai Fhitung < Ftabel $(0.673$ $<3.114)$. Hal ini berarti tidak terdapat perbedaan yang signifikan pada variabel motivasi melanjutkan pendidikan ke perguruan tinggi ditinjau dari usia remaja panti asuhan"X". Hasil dalam penelitian ini sejalan dengan penelitian yang dilakukan oleh Wulandari \& Rola (2004), bahwa tidak terdapat perbedaan yang signifikan yang ditinjau dari usia.

\section{Kesimpulan}

Kesimpulan penelitian ini, terdapat hubungan signifikan yang positif antara konsep diri dengan motivasi melanjutkan pendidikan ke perguruan tinggi remaja panti asuhan "X". Adapun saran yang dapat diberikan, antara lain untuk remaja panti asuhan, dengan memiliki konsep diri yang positif, diharapkan remaja dapat memahami serta menerima kelebihan dan kekurangan diri serta memaksimalkan potensi sehingga motivasi melanjutkan pendidikan ke perguruan tingginya meningkat dengan catatan memiliki pandangan yang baik terhadap fisik, sosial, moral dan psikisnya. Pengurus panti asuhan perlu memberikan motivasi atau menjalin kerjasama dengan universitas yang memiliki program studi psikologi maupun melalui kumpul rutin dengan remaja panti untuk membentuk konsep diri yang positif anak asuh sehingga motivasi remaja untuk melanjutkan pendidikan ke perguruan tingginya meningkat. Bagi peneliti selanjutnya disarankan untuk meneliti pengaruh lain dari motivasi melanjutkan pendidikan ke perguruan tinggi seperti kemampuan kognitif, tingkat ekonomi, latar belakang sosial sehingga dapat melengkapi temuan pada penelitian ini secara lebih mendalam.

\section{Referensi}

Aditi, F. A. (2012). Hubungan konsep diri dengan motivasi belajar siswa kelas xi di sma negeri 7 padang tahun 2012 (Unpublished undergraduate thesis). Univeritas Andalas, Padang.

Ali, M. (2017). Banyak lulusan sma/smk ogah lanjutkan kuliah. Purworejo.sorot.co. Diakses September, 27, 2018 dari http://purworejo.sorot.co/berita-4638-banyak-lulusansmasmk-ogah-lanjutkan-kuliah-.html.

Arikunto, S. (2006). Prosedur Penelitian Suatu Pendekatan Praktik. Jakarta: PT. Rineka Cipta.

Azwar, S. (2011). Metode penelitian, Edisi I Cetakan XII. Yogyakarta: Pustaka Pelajar.

Berzonsky, M.D. (1981). Adolescent development. New York: Mac Milan Publishing. Co Inc.

Biantara, G. (2016, November). Manfaat melanjutkan pendidikan ke perguruan tinggi. Gilangbiantara.com. Diakses September, 15, 2018 dari http://gilangbiantara.com/manfaatmelanjutkan-pendidikan-ke-perguruan-tinggi/.

Calhoun, F., \& Acocella, J. R. (1990). Psikologi Tentang Penyesuaian dan Hubungan Kemanusiaan (edisi ketiga). Semarang: IKIP Semarang Press.

Cherniss, C., \& Goleman, D. (2001). The emotionally intelligent workplace: How to select for, measure, and improve emotional intelligence in individuals, groups, and organizations. San Fransisco: Jossey-Bass.

Hamalik, O. (1992). Media Pendidikan. Bandung: Penerbit Alumni.

Hartiyani, N. (2011). Hubungan konsep diri dan kepercayaan diri dengan interaksi sosial remaja panti asuhan nur hidayah Surakarta [Undergraduate thesis, Universitas Sebelas Maret Surakarta]. https://digilib.uns.ac.id/dokumen/detail/20936

Huitt, W. (2009). Self concept and self esteem. Edpsycinteractive.org. Diakses May, 2, 2018 dari www.edpsycinteractive. org/topics/conation/self.html.

Khan, A., \& Alam, S. (2015). Self-concept in relation to achievement motivation of high school students. The International Journal of Indian Psychology, 2(4), 62-71.

Khoirunnisa, S., Ishartono, I., \& Resnawaty, R. (2015). Pemenuhan kebutuhan pendidikan anak asuh di panti sosial asuhan anak. Prosiding Penelitian dan Pengabdian kepada Masyarakat, 2(1), 69-73. https://doi.org/10.24198/ jppm.v2i1.13258

Lawrence, A. S., \& Vimala, A. (2013). Self-concept and achievement motivation of high school students. Online Submission, 1(1), 141-146. 
Lestari, P. (2016). Pentingnya pendidikan bagi bangsa Indonesia. Cnnindonesia.com. Diakses Juni, 27, 2018 dari https: //student.cnnindonesia.com/inspirasi/20160114104154-322104215/pentingnya-pendidikan-bagi-bangsa-indonesia/

Mazaya, K. N., \& Supradewi, R. (2021). Konsep diri dan kebermaknaan hidup pada remaja di panti asuhan. Proyeksi: Jurnal Psikologi, 6(2), 103-112. urlhttp://dx.doi.org/10.30659/jp.6.2.103-112

Mecadinisa, N. (2018, Juli). Berdasarkan survei, 90 persen anak di 8000 panti asuhan masih punya orangtua. www.liputan6.com. Diakses Oktober, 23, 2018 dar https://www.liputan6.com/fashion-beauty/read/3605338/ berdasarkan-survei-90-persen-anak-di-8000-panti-asuhanmasih-punya-orangtua.

Merina, R. S. (2014). Konseling kelompok untuk meningkatkan konsep diri remaja di panti asuhan. Psychological Journal: Science and Practice, 2(2). https://ejournal.umm.ac.id/index. php/pjsp/article/view/2154
Ningrum, N. A. (2012). Hubungan antara coping strategy dengan kenakalan pada remaja awal. Jurnal Psikologi Tabularasa, $7(1), 481-489$.

Sahuleka, J. M. (2003). Panti asuhan sebagai suatu lingkungan bagi perkembangan anak (Unpublished undergraduate thesis). Universitas Indonesia, Jakarta.

Sardiman, A. M. (2014). Interaksi dan Motivasi BelajarMengajar. Depok: PT Rajagrafindo Persada.

Schunk, D. H., Pintrich, P. R., \& Meece, J. L. (2012). Motivasi dalam Pendidikan: Teori, Penelitian, dan Aplikasi. Jakarta: PT. Indeks.

Septiana, N. P. (2014). Hubungan antara konsep diri dengan motivasi berprestasi pada siswa sma negeri 3 sragen. Naskah Publikasi. Universitas Muhammadiyah Surakarta.

Wulandari, L. H., \& Rola, F. (2004). Konsep diri dan motivasi berprestasi remaja penghuni panti asuhan. Jurnal Ilmu Pemberdayaan Komunitas, 3(2), 81-86. 